\title{
Strategi Pemerintah Daerah dalam Meningkatkan Pelayanan Pada Masyarakat Melalui Sistem Pemerintahan Berbasis Elektronik
}

\author{
${ }^{1}$ Widya Kurniati Mohi, ${ }^{2}$ Nuzlan Botutihe \\ ${ }^{12}$ Program Studi Administrasi Publik, Universitas Muhammadiyah Gorontalo, \\ Gorontalo, Indonesia 96181 \\ E-mail: ${ }^{1}$ widyakurniati@umgo.ac.id ; ${ }^{2}$ nuzlanbotutihe@umgo.ac.id
}

Received: 16 Oktober 2020; Revised: 26 Oktober 2020; Accepted: 18 Desember 2020

\begin{abstract}
This article aims to analyze and find out the strategies implemented by the Regional Government, especially the Kelurahan Governments in Gorontalo District in providing maximum service to the community. This study uses qualitative research methods with the intention of comprehensively knowing several things related to the implementation of E-Gov and to reveal the phenomena that occur in the application of E-Gov. The results showed that the capacity or ability of the Gorontalo District government in implementing the $\neg E$-Gov concept needs to be evaluated and continuously improved, especially in relation to the budget. This can be seen from the limited funds that are not allocated specifically for the Electronic Government, the limited allocation of funds that have been budgeted by the Government in Gorontalo District is still insufficient for E-Government development, so that activities carried out follow the amount of the budget given, in other words the budget can affect effectiveness of the implementation of activities carried out in the application of E-Government, so that the use and utilization of the budget must be effective and efficient. the implementation of $E$ Gov in Gorontalo District has been going well. However, there are still some obstacles that are faced, this can be seen from the human resources recruited to manage the Electronic Government who do not have the competence and expertise in this field and some do not even have expertise in the technology field. This is a big challenge for the Gorontalo District government
\end{abstract}

Keywords:Strategy; Regional Government; Electronic Systems

\begin{abstract}
Abstrak
Artikel ini bertujuan menganalisis dan mengetahui strategi yang dilakukan Pemerintah Daerah khususnya Pemerintah Kelurahan yang ada di Kabupaten Gorontalo dalam memberikan pelayanan yang maksimal kepada masyarakat. Penelitian ini menggunakan metode penelitian kualitatif dengan maksud untuk mengetahui secara komprehensif beberapa hal terkait dengan pelaksanaan E-Gov dan mengungkap fenomena yang terjadi dalam penerapan E-Gov. Hasil penelitian menunjukkan kapasitas atau kemampuan pemerintah Kabupaten Gorontalo dalam menerapkan konsep E-Gov perlu dilakukan evaluasi dan terus ditingkatkan terutama terkait dengan anggaran. Hal ini terlihat dari keterbatasan dana yang tidak dialokasikan khusus untuk Electronic Government,terbatasnya alokasi dana yang telah dianggarkan oleh Pemerintah di Kabupaten Gorontalo masih belum mencukupi untuk pengembangan E-Government, sehingga kegiatan yang dilakukan mengikuti jumlah anggaran yang diberikan, dengan kata lain anggaran dapat mempengaruhi efektivitas pelaksanaan kegiatan yang dilakukan di dalam penerapan E-Government, sehingga penggunaan dan pemanfaatan anggaran harus efektif dan efisien.penerapan E-Gov di Kabupaten Gorontalo sudah berjalan dengan baik. Namun, masih ada beberapa kendala yang dihadapi, hal ini dapat dilihat dari sumber daya manusia yang direkrut dalam mengelola Electronic Government belum memiliki kompetensi dan keahlian di bidang tersebut bahkan ada yang tidak memiliki keahlian di bidang teknologi
\end{abstract}

Kata Kunci:Strategi; Pemerintah Daerah; Sistem Elektronik

Link DOI : http://dx.doi.org/10.31314/pjia.9.2.115-124.2020 


\section{PENDAHULUAN}

Teknologi informasi dan komunikasi (TIK) dengan internet sebagai prodak unggulannya pada dasarnya adalah gotong royong elektronik terbesar. Betapa tidak satu perangkat komputer yang kita punya bisa dihubungkan dengan jutaan komputer sedunia. Dengan demikian betapa besarnya sinergitas yang dihasilkan dari kerjasama jutaan komputer, tanpa memandang siapa yang mengoperasikan, apakah dari kalangan mana, kulit hitam, putih atau berwarna. Juga tanpa memandang golongan politik dan ideologi.

Gotong royong ini memang luar biasa, menembus banyak negara tanpa batas. Mereka bersedia bergabung dengan gotong royong elektronik melalui ini, suatu perubahan yang besar dari budaya abad informasi ini. Kini perkembangan dunia informasi sudah begitu pesat, makin hari penemuan teknologi informasi ini semakin canggih dan semakin murah, sehingga efieiseni yang dijanjikan menjadi semakin menarik minat masyarakat(Sudarto,2006).

Upaya yang harus dilakukan untuk mengatasi kondisi tersebut adalah memperbaiki kualitas penyelenggaraan pelayanan publik yang berkesinambungan dalam rangka mewujudkan pelayanan publik sesuai harapan masyarakat, karena pelayanan publik merupakan fungsi utama pemerintah yang akan diberikan kepada publik. Oleh sebab itu penyelenggaraan pelayanan publik akan terwujud apabila prinsip dari Good Governance diterapkan. Salah satu ciri dari tata kelola pemerintahan yang baik (Good Governance) adalah pada kualitas pelayanan. Oleh sebab itu pemanfaatan perkembangan teknologi informasi dan komunikasi merupakan upaya yang dilakukan pemerintah (Neneng Siti Maryam 2016).
Perkembangan teknologi informasi dan komunikasi telah menawarkan solusi dalam meningkatkan kinerja pelayanan pubik yang dapat mewujudkan prinsipprinsip Good Governance. Di era globalisasi seperti sekarang ini dimana teknologi informasi dan komunikasi berkembang dengan pesat tentu mempengaruhi berbagai sektor kehidupan termasuk di bidang pemerintahan yang diwujudkan dalam sebuah sistem yang disebut Electronic Government (E-Gov). electrnic Government merupakan suatu sistem dimana pemerintah memanfaatkan kemajuan teknologi informasi dan komunikasi dalam proses pemerintahan baik dalam memberikan pelayanan, pengelolaan keuangan, perumusan kebijakan dan (Jiko Tri Nugraha 2018).

Belakangan ini Telah banyak Negara yang telah bertransformasi dalam meningkatkan pelayanannya dari cara Tradisional ke cara yang memanfaatkan Teknologi Informasi, yang berbasis internet. Termasuk Indonesia yang telah mengadopsi konsep Elektronik Government (E-Gov) sebagai upaya dalam meningkatkan kinerja Pemerintahan (Hardjaloka,2014).

Semakin besarnya peran teknologi informasi dan komunikasi (TIK) dalam proses bisnis membuat banyak lembaga berlomba mengimplementasikan TIK untuk proses terintegrasi. Berdasarkan hasil evaluasi, pengembangan e-Gov di Indonesia masih dijumpai banyak problem yang secara umum berpangkal dari kesalahan pandangan atau paradigma tentang E-Gov. Faktor teknis dan non teknis penghambat E-Gov juga telah diidentifikasi dalam beberapa kajian. Interoperabilitas antar aplikasi juga menjadi tuntutan mendesak dalam pengembangan e-Gov di Indonesia. Hal ini disebabkan oleh kebutuhan data 
multisektoral dalam rangka pengambilan kebijakan untuk mengatasi problem yang melibatkan data dari antar sektor terkait (Istiyanto \& Sutatnta, 2012).

Permasalahan klasik yang kemudian didapatkan kemudian tidak terlepas dari permasalahan klasik yang sebenarnya hampir terjadi di setiap wilayah yang ada di Indonesia, seperti fasilitas sarana jaringan (Server), Kapasitas SDM dan pemahaman publik terhadap layanan EGov Sendiri seperti pada penelitian Nur (2014), Sosiawan, (2015) dan penelitian Irawan (2018) menunjukkan permasalahan sarana menjadi kendala dalam layanan EGov.

Hal ini juga yang kemudian terjadi di di Kabupaten Gorontalo. Dimulai dari keterbatasan fasilitas Sistem Jaringan (IT), kapasitas Sumber daya (Operator pelaksana) hingga masyarakat yang kurang memahami bagaimana mengurus segala urusan administrasi berbasis IT dikarenakan ada beberapa pertimbangan dari sisi kebudayaan yang masih dijunjung oleh sebagian masyarakat sehingga masyarakat masih terkesan "tabuh" dalam menggunakan fasilitas E-Gov. yang penulis dapatkan dalam observasi awal di beberapa kelurahan yang ada. Pada dasarnya Pemerintah Daerah sudah berupaya dan telah menerapkan Strategi dalam meningkatkan pelayanan berbasis SPBE di beberapa instansi tersebut, namun kenyataannya didapatkan fakta bahwa pelayanan berbasis.

SPBE (Sistem Pemerintahan Berbasis Elektronik) berdasarkan Perpres Nomor 95 2018 tentang SPBE diturunkan dengan Perbup Nomor 50. Tahun 2019 tersebut kemudian masih menemui beberapa kendala, yakni pemahaman masyarakat masih kurang tentang sistem Pemerintahan Berbasis Elektroik, begitupun dengan sosialisasi tentang E-Gov baru sampai ke internal Aparatur Sipil Negara (ASN) belum mencakup semua masyarakat secara merata.

Sehingganya penelitian ini kemudian dilakukan untuk mengetahui sekaligus menganalisis bagaimana Strategi yang dilakukan oleh Pemerintah Daerah dalam meningkatkan pelayanan pada masyarakat berbasis SPBE. Manfaat dari penelitian ini nantinya untuk mendapatkan data komprehensif terkait strategi dalam pelaksanaan SPBE di Kabupaten Gorontalo, yang nantinya dapat menjadi bahan dalam analisis kebijakan dalam pelayanan publik berbasis SPBE.

Adapun kajian penelitian yang relevan mengenai penelitian ini yakni :

Hasil penelitian dari Edy Susena, dan Dewi Amelia Lestari (2016) mengenai "Efektivitas Penerapan Electronic Government Terhadap Pelayanan Publik Di Kabupaten Sragen", dari hasil peneltian menunjukkan bahwa Electronic Government di kabupaten Sragen sudah efektif penerapannya hal ini dibuktikan dengan pemerintah Kabupaten Sragen sudah berhasil menyusun e-goverment dengan baik hal ini berdampak pada meningkatnya pelayanan publik di Kabupaten Sragen dan masyarakatnya telah memanfaatkan E-Government di kabupaten Sragen dengan baik dan saat ini pemerintah sedang mengupayakan perawatan dan mengembangkan sistemsistem yang diperlukan oleh pemerintah dan masyarakat

Perbedaan penelitian ini dengan penelitian terdahulu mengenai Electronic Government adalah pada kajian teori yang digunakan dalam menganalisis penerapan Electronic Government. Dalam Penelitian ini menggunakan hasil kajian dari Hardvard JKF School of Government (Indrajit 2004), untuk melihat seberapa jauh pelaksanaan Electronic Government yang dinilai dari tiga elemen yaitu support, capacity dan value. Selain itu, penelitian Copyright @ 2020, Publik (Jurnal Ilmu Administrasi), ISSN: 2301-573X (Print), ISSN: 2581-2084 (Online) 
ini mengkaji realisasi dari penerapan $E$ Gov.

\section{METODE PENELITIAN}

Penelitian direncanakan dilaksanakan maksimal selama bulan Agustus 2020September 2020 yang meliputi tahap pengusulan, persiapan,proses penelitian, pengolahan data, dan penyusunan laporan. Sedangkan lokasi penelitian dilaksanakan di Kantor Sekretariat Daerah Gorontalo dan Dinas Kominfo Gorontalo.

Penelitian ini menggunakan jenis penelitian deskriptif dengan pendekatan kualitatif, penelitian deskriptif didasarkan pada pertimbangan bahwa data akan diperoleh dengan lebih lengkap, mendalam dan terpercaya serta dapat ditemukan kejadian dalam konteks sosial. Data yang bersifat keyakinan, kebiasaan, sikap mental, dan budaya yang dianut oleh seorang dapat dikemukakan dengan jelas Secara kualitatif bertujuan untuk mengetahui atau menggambarkan kenyataan dari kejadian yang diteliti sehingga memudahkan penulis untuk mendapatkan data yang objektif dalam rangka mengetahui, memahami Strategi Pelayanan Publik Berbasi Elektronik Government di Lokasi Penelitian yang telah ditetapkan. Populasi Penelitian ini nantinya berada di Kantor Sekretariat Daerah dan Dinas Kominfo Kabupaten Gorontalo yang ada Informan di setiap Dinas terkait. Selanjutnya informan maupun key informan.ditentukan dengan teknik purposive sampling

Adapun informan yang dipilih adalah sebagai berikut:Asisten 1 Setda Kabupaten Gorontalo, Kepala Bagian Tata Pemerintahan Setda Kabupaten Gorontalo, Kepala Bagian Ekonomi Pembangunan Setda Kabupaten Gorontalo, Kepala Sub Bagian Hukum Setda Kabupaten Gorontalo. Kepala Bidang Aplikasi dan
Informatika Dinas Komunikasi dan Informatika Kabupaten Gorontalo dan staff/operator IT

Sumber data yang digunakan terdiri dari sumber data primer yaitu melalui wawancara dengan informan dan melakukan observasi lapangan dan sumber data sekunder yaitu berupa catatan-catatan yang diperoleh dari lapangan. Metode pengumpulan data menggunakan wawancara, observasi dan dokumentasi. Analisis data menggunakan teknik analisis dari Miles, Huberman, dan Saldana (2014).

Adapun aktivitas dalam analisis data nantinya ialah Reduksi data (Data Reduction), Menampilkan Data (Data Display) dan Verifikasi data (Data Verification).

\section{HASIL DAN PEMBAHASAN}

Electronic Government secara umum didefinisikan sebagai pemanfaatan teknologi informasi dan komunikasi untuk mentransformasikan kegiatan pemerintah, yang bertujuan untuk meningkatkan efektivitas dan efisiensi serta penyampian layanan (Forman et al, 2005). Istilah Electronic Government mengarah pada pemanfaatan teknologi digital dalam organisasi pemerintahan agar terwujudnya sebuah organisasi yang lebih efektif dan transparan. Melalui Electronic Government diharapkan pelayanan terhadap masyarakat dapat lebih baik, efektivitas internal organisasi pemerintahan semakin meningkat dan akses masyarakat terhadap informasi dalam lingkungan pemerintahan semakin mudah (Kase, 2010; Nugraha,2018; Aprilia et al., 2014).

Penelitian mengenai Elektronik Government (E-Gov) pada dasarnya sudah banyak dilakukan oleh para akademisi maupun praktisi yang ada di Indonesia namun riset yang dilakukan lebih banyak menjelaskan implementasi dan evaluasi 
dari pelaksanaan E-Gov. untuk penelitian yang akan dilakukan nantinya lebih melihat bagaimana Analisis Strategi yang telah dilakukan dalam Pelayanan Publik oleh Pemda Kabupaten Gorontalo, dengan pertimbangan kearifan lokal yang dimiliki oleh Masyarakat Gorontalo. Sehingga hal ini kemudian menjadi pembeda dengan beberapa riset sebelumnya. Kontribusi keilmuan dalam penelitian ini nantinya juga akan nampak terkait bagaimana konsep Pemerintahan kekinian dengan paradigma baru dapat dipadupadankan dengan konsep kearifan lokal yang dimiliki oleh sebagian besar masyarakat Indonesia

Berdasarkan hasil kajian dari Hardvard JKF School of Government, dalam menerapkan konsep Electronic Government pada sektor publik, ada tig elemen sukses yang harus diperhatikan yaitu Support; Capacity dan Value. Berikut adalah uraian pembahasan dari ketiga elemen sukses dalam konsep Electronic Government yaitu:

\section{Support}

Penerapan konsep Electronic Government tidak akan berjalan baik apabila tidak ada dukungan dari pihak pemerintah dan masyarakat. Dukungan pelaksanaan konsep Electronic Government dapat efektif apabila mulai dilakukan oleh pimpinan pemerintahan pusat kemudian pemerintahan daerah, hal ini diakibatkan oleh budaya birokrasi yang bekerja dengan model manajemen top down. Adapun dukungan yang dimaksudkan adalah dalam bentuk kesepakatan bersama dari pihak pemerintah untuk menerapkan konsep digitalisasi dalam pelayanan publik sehingga akan terwujud sebuah pelayanan yang efektif, efisien dan transparan serta akuntabel.

Impelementasi konsep Electronic Government yang efektif harus mendapatkan dukungan dari seluruh Copyright @ 2020, Publik (Jurnal Ilmu Administrasi), ISSN: 2301-573X (Print), ISSN: 2581-2084 (Online) kemampuan yang dimiliki pemerintah

elemen pemerintahan. Peran pimpinan menjadi hal yang sangat penting dalam mendukung penerapan Electronic Government yang bukan hanya menyusun konsep, tetapi harus menjadi motivator pada proses pelaksanaan konsep tersebut.

Dalam penelitian ini, yang dimaksudkan dengan support atau dukungan adalah bagaimana peran pemerintah Kabupaten Gorontalo dalam mendukung penerapan konsep E-Gov agar terwujudnya sebuah pelayanan publik yang efektif dan efisien. Berdasarkan hasil penelitian dan analisis penulis dapat diketahui bahwa penerapan konsep Electronic Government mendapat dukungan yang luar biasa baik dari pemerintah Kabupaten Gorontalo bahkan pemerintah Desa yang ada dilingkungan Kabupaten Gorontalo. Hal ini terlihat dari adanya relasi antara pemerintah Kecamatan dan Desa dalam mengalokasikan berbagai sumber daya (manusia, finansial, tenaga, waktu, informasi).

Kesungguhan Pemerintah Kabupaten Gorontalo dalam mengembangkan Electronic Government dapat dilihat dari beberapa fitur layanan yang sudah mulai dikembangkan berbasis digital, meski belum menjangkau semua pelayanan. Penyetoran jumlah pajak melalui EBilling,penginputan dan saat ini sedang diupayakan sebuah Sistem Informasi yaitu sebuah aplikasi yang memuat seluruh informasi terkait Profil wilayah Kabupaten Gorontalo. Selain itu, pemerintah juga melakukan sosialisasi kepada masyarakat terkait pemanfaat teknologi informasi di bidang pemerintahan, melalui pertemuanpertemuan tertentu dengan masyarakat dan melalui media sosial.

\section{Capacity}

Capacity adalah adanya unsure 
dalam mewujudkann konsep Electronic Government. Dalam penelitian ini, ada tiga hal yang perlu diperhatikan pemerintah, yaitu adanya pengalokasian anggaran untuk pelaksanaan konsep Elcetronic Government, ketersediaan infrastruktur teknologi informasi serta fasilitas pendukung lainnya dan ketersediaan sumber daya manusia sebagai pengelola Electronic Government tentu harus mempunyai kompetensi dan keahlian yang sesuai. Dapat diuraikan sebagai berikut

\section{a. Sumberdaya Finasial}

Sumberdaya finansial adalah salah satu aspek penting dalam menunjang penerapan Electronic Govermenti dalam suatu daerah. Sumberdaya finansial perlu dipersiapkan dengan baik untuk persiapan penerapan Electronic Government. Berdasarkan hasil penelitian dan analisis peneliti dapat diketahui bahwa kapasitas atau kemampuan pemerintah Kabupaten Gorontalo dalam menerapkan konsep EGov perlu dilakukan evaluasi dan terus ditingkatkan terutama terkait dengan anggaran. Hal ini terlihat dari keterbatasan dana yang tidak dialokasikan khusus untuk Electronic Government, oleh sebab itu saat ini pemerintah Kabupaten Gorontalo bekerja sama dengan Pemerintah Desa yang berada di lingkungan Kecamatan menganggarkan dana untuk pengembangan E-Government melalui Dana Desa. Terbatasnya alokasi dana yang telah dianggarkan oleh Pemerintah di Kabupaten Gorontalo masih belum mencukupi untuk pengembangan E-Government, sehingga kegiatan yang dilakukan mengikuti jumlah anggaran yang diberikan, dengan kata lain anggaran dapat mempengaruhi efektivitas pelaksanaan kegiatan yang dilakukan di dalam penerapan E-Government, sehingga penggunaan dan pemanfaatan anggaran harus efektif dan efisien.

\section{b. Kelengkapan Infrastruktur}

Infrastruktur merupakan keperluan fisik yang harus disediakan oleh organisasi sebagai alat dan layanan atau fasilitas agar sistem berjalan dengan maksimal. Infrastruktur merupakan peran penting di dalam kaitannya dengan penerapan EGovernment.

Kondisi infrastruktur untuk penerapan E-Government di Kabupaten Gorontalo masih belum optimal. Hal ini terlihat dari pemerintah setempat sering mengalami kendala pada ketersediaan jaringan internet yang jangkauannya belum luas, kemudian sistem jaringan yang sering mengalami gangguan yang mengakibatkan keterlambatan penyampaian infromasi melalui media online, selain itu juga beberapa wilayah di Kabupaten Gorontalo sebagian berada di pelosok yang sulit dijangkau jaringan sehingga mengakibatkan penerapan Electronic Government di wilayah tersebut mengalami hambatan.

\section{c. Sumberdaya Manusia}

Sumberdaya manusia merupakan faktor yang berpengaruh dalam pelaksanaan konsep Electronic Government. Ketersediaan sumberdaya manusia dalam hal ini adalah pengelola Electrnic Government harus memiliki kompetensi dan keahlian dibidang teknologi sehingga sesuai dengan konsep Electronic Government.

Berdasarkan hasil wawancara penerapan E-Gov di Kabupaten Gorontalo sudah berjalan dengan baik. Namun, masih ada beberapa kendala yang dihadapi, hal ini dapat dilihat dari sumber daya manusia yang direkrut dalam mengelola Electronic Government belum memiliki kompetensi dan keahlian di bidang tersebut bahkan ada yang tidak memiliki keahlian di bidang teknologi. Hal ini menjadi tantangan besar bagi pemerintah Kabupaten Gorontalo. Namun saat ini, baik Pemerintah 


\section{Available Online at http://journal.umgo.ac.id/index.php/Publik \\ Publik (Jurnal Ilmu Administrasi) Vol 9 (2), Desember 2020}

Kecamatan maupun Desa saling bekerja sama untuk terus melakukan upaya-upaya agar konsep $\mathrm{E} \neg-\mathrm{Gov}$ dapat terealisasi, di mulai dari memberikan pelatihan atau bimbingan teknis kepada para aparat untuk meningkatkan keahlian dalam mengoperasikan aplikasi lebih khusus.

\section{Value}

Elemen ketiga adalah value yang berarti penerapan konsep Electronic Government harus ada implikasi yang diperoleh baik pemerintah maupun masyarakat. Hasil wawancara dengan informan di Kabupaten Gorontalo menyatakan bahwa penerapan konsep digitalisasi dalam lingkup pelayanan masyarakat mendapatkan kemudahan, selain itu diharapkan adanya peningkatan literasi terkait konsep tersebut mengingat belum seluruhnya warga masyarakat paham akan konsep Electronic Government.

Sosialisasi pemanfaatan Electronic Government paling efektif adalah melalui interaksi langsung antara pemerintah dengan masyarakat. penerapan konsep Electronic Government selain dapat meningkatkan kinerja pemerintah, namun juga berarti adanya transformasi penyelenggaraan pemerintahan yang berpusat masyarakat (demokrasi). Sosialisasi belum dilaksanakan secara luas sampai pada masyarakat.

Studi Electronic Government sebenarnya telah banyak yang melakukan penelitian dan mengkaji penerapannya di Indonesia. Pada penelitian ini, ada beberapa penelitian terdahulu yang menjadi perbandingan. Hasil penelitian dari Nunik Retno Herawati (2014) dengan judul Penerapan Electronic Government Dalam Mendorong Terwujudnya Penyelenggaraan Pemerintahan Yang Baik: Studi Kasus Penelitian Kabupaten/Kota Jawa Tengah, menjelaskan bahwa Electronic Government di Kabupaten/Kota Copyright @ 2020, Publik (Jurnal Ilmu Administrasi), ISSN: 2301-573X (Print), ISSN: 2581-2084 (Online) di Jawa Tengah sudah diterapkan hal ini dibuktikan dengan adanya situs web dari pemerintah Kabupaten/Kota di Jawa Tengah, namun dalam penerapannya pemerintah setempat masih mengalami kendala diantaranya adalah beberapa situs web yang tidak bisa diakses, mengenai transparansi pengelolaan keuangan daerah hanya ada beberapa situs web Kabupaten yang memiliki tampilan mengenai pengelolaan keuangan. Selain itu, hasil penelitian dari Siti Mutia Nurcahyani Liputo (2015) "Penerapan E-Government Kelurahan Di Kantor Kelurahan Karampuang Kecamatan Panakkukang Kota Makassar", Hasil penelitian adalah penerapan Electronic Government di Kantor Kelurahan Karampuang telah cukup optimal. Hasil penelitian tersebut menyatakan bahwa setelah adanya penerapan konsep Electronic Government dalam proses pelayanan publik oleh pemerintah Kelurahan Karampuang sudah cukup maksimal. Hal ini terlihat dari proses pemberian pelayanan melalui EGovernment kelurahan Karampuang lebih efektif dan efisien dibandingkan sebelumnya. Melalui penerapan Konsep Electronic Government di kelurahan Karampuang tersebut membawa dampak baik bagi masyarakat yang menerima pelayanan.

Hasil penelitian dari Edy Susena, S.Kom, M.Kom, dan Dewi Amelia Lestari, S.Kom, MM (2016) "Efektivitas Penerapan Electronic Government Terhadap Pelayanan Publik Di Kabupaten Sragen", dari hasil peneltian menunjukkan bahwa Electronic Government di kabupaten Sragen sudah efektif penerapannya hal ini dibuktikan dengan pemerintah Kabupaten Sragen sudah berhasil menyusun e-goverment dengan baik hal ini berdampak pada meningkatnya pelayanan publik di Kabupaten Sragen dan masyarakatnya telah memanfaatkan E- 
Government di kabupaten Sragen dengan baik dan saat ini pemerintah sedang mengupayakan perawatan dan mengembangkan sistem-sistem yang diperlukan oleh pemerintah dan masyarakat.

Beberapa penelitian terdahulu mengenai penerapan Electronic Government dapat diambil kesimpulan bahwa, Electronic Government telah diterapkan dan berjalan dengan baik. Namun terlepas dari hal tersebut, penerapan Electronic Government masih mengalami kendala secara garis besar masalahnya ketersediaan infrastruktur yang memadai, situs web yang tidak bisa diakses dan lain sebagainya. Hal ini tidak berbeda jauh dengan penelitian yang dilakukan di Kabupaten Gorontalo, hasil penelitian menunjukan penerapan Electronic Governemnt di Kabupaten Gorontalo mengalami beberapa kendala diantaranya adalah kurangnya ketersediaan sumber daya manusia yang memiliki kompetensi dan keahlian dibidang teknologi informasi, kemudian terbatasnya infrastruktur teknologi dan kurangnya pemahaman masyarakat terkait dengan perkembangan teknologi yang ada dan tidak adanya alokasi dana khusus untuk pengelolaan Electronic Government. Namun, saat ini pemerintah terus melakukan evaluasi terkait dengan hal tersebutagar penerapan Electronic Government di Kabupaten Gorontalo dapat terealisasi dengan baik.

Penelitian mengenai studi Electronic Government ini dilakukan dengan tujuan untuk bagaimana mengetahui dan melihat perkembangan dari penerapan E-Gov sendiri khususnya di Kabupaten Gorontalo Kabupaten Gorontalo dan secara umum di Indonesia. Adapun hasil dari penelitian ini diharapkan dapat menjadi suatu bahan studi perbandingan untuk Pemerintah dalam melakukan pengembangan
Electronic Government dalam rangka meningkatkan pelayanan publik, dan transparansi serta akuntabilitas dalam sistem pemerintahan. Selain itu penelitian tentang studi Electronic Government ini dapat dijadikan sebagai perbandingan selanjutnya dan akan menjadi bahan masukan dalam pemikiran ilmiah untuk kelengkapan kajian menegenai perkembangan ilmu pengetahuan, terutama yang berhubungan dengan persoalan pengembangan konsep Electronic Government.

\section{PENUTUP}

\section{Kesimpulan}

Penerapan Electronic Government di Kabupaten Gorontalo sudah berjalan dengan baik. Hal tersebut dapat dilihat dari adanya dukungan yang luar biasa dari pemerintah Kabupaten Gorontalo untuk pelaksanaan konsep E-Gov dalam rangka penyelenggaraan pelayanan publik, hal ini terlihat dari adanya beberapa aktivitas pemerintahan yang sudah berbasis aplikasi. Pada sisi kemampuan, secara umum pemerintah Kabupaten Gorontalo masih mengalami kendala terutama dalam hal penyediaan infrastruktur yang belum memadai dan ketersediaan sumber daya manusia dalam hal ini pengelola sistem EGov yang belum memiliki kompetensi dan keahlian di bidang teknologi. Namun secara keseluruhan baik pemerintah maupun masyarakat merasakan adanya manfaat dari penerapan E-Gov. Masyarakat lebih merasakan adanya keterbukaan informasi, mendapat pelayanan yang efektif dan efisien serta pemerintah lebih transparan dan akuntabel dalam memberikan pelayanan.

\section{Saran}

Berdasarkan hasil penelitian yang telah dijelaskan sebelumnya maka saran 


\section{Available Online at http://journal.umgo.ac.id/index.php/Publik \\ Publik (Jurnal Ilmu Administrasi) Vol 9 (2), Desember 2020}

Jurnal IImu Administrasi

yang dapat diberikan agar pelaksana pengembangan Electronic Government dapat berjalan semakin optimal adalah sebagai berikut :

1. Pengembangan kapasitas sumberdaya manusia khususnya aparatur pemerintah masih perlu dilakukan untuk meningkatkan kemampuan aparatur pemerintah secara terus menerus.

2. Perlu adanya peningkatan jumlah sarana dan prasarana infrastruktur pendukung penerapan Electronic Government.

3. Perlu pengalokasian dana khusus untuk pengembangan Electronic Government di Kabupaten Gorontalo

4. Perlu adanya sosialisasi secara terus menerus kepada masyarakat tentang keberadaan penerapan Electronic Government dan pemanfaatannya.

5. Perlunya kerja sama dengan berbagai stakeholder untuk mensiasati hambatan-hambatan yang muncul dalam penerapan Electronic Government.

\section{DAFTAR PUSTAKA}

Aprilia, S. N., Wijaya, A. F., \& Suryadi, S. (2014). Efektivitas Website Sebagai Media E-Government dalam Meningkatkan Pelayanan Elektronik Pemerintah Daerah (Studi Pada Website Pemerintah Daerah Kabupaten Jombang). Wacana Journal of Social and Humanity Studies, 17(2), 126-135.

Forman, C., Goldfarb, A., \& Greenstein, S. (2005). Geographic location and the diffusion of Internet technology. Electronic Commerce Research and Applications, 4(1), 1-13.

Hardjaloka, L. (2014). Studi penerapan egovernment di indonesia dan negara lainnya sebagai solusi pemberantasan korupsi di sektor publik. Jurnal Rechts Vinding: Media Pembinaan Hukum Nasional, 3(3), 435-452.

Indrajit, Richardus Eko. (2004) Electronic Government "Strategi Pembangunan Sistem Pelayanan Publik Berbasis Teknologi Digital”. Yogyakarta, Andi

Joko Tri Nugraha. (2018). E-Government Dan Pelayanan Publik (Studi Tentang Elemen Sukses Pengembangan E-Government Di Pemerintah Kabupaten Sleman). Jurnal Komunikasi Dan Kajian Media (Volume 2, No.1)

Miles, M.B, Huberman,A.M, dan Saldana,J. (2014). Qualitative Data Analysis, A. Methods Sourcebook Edition 3.

Irawan, A. (2018). Sistem Pelayanan Publik Berbasis E-Government Pada Pemerintah Daerah Kabupaten Merauke. Societas: Jurnal Ilmu Administrasi Dan Sosial, 7(1), 20-37.

Istiyanto, J. E., \& Sutanta, E. (2012). Model Interoperabilitas Antar Aplikasi e-Government. Jurnal Teknologi Technoscientia, 137-148.

Kase, J. (2010). Perencanaan StrategisSistem Informasi (SI) Pada Pemerintah Kabupaten Timor Tengah Selatan. Thesis, Universitas GadjahMada.

Neneng Siti Maryam. (2016). Mewujudkan Good Governance Melalui Pelayanan Publik. Jurnal Ilmu Politik Dan Komunikasi (Volume VI No. 1)

Nugraha, J. T. (2018). E-Government Dan Pelayanan Publik (Studi Tentang Elemen Sukses Pengembangan EGovernment Di Pemerintah Kabupaten 
Sleman). Jurnal Komunikasi dan Kajian Media, 2(1), 32-42.

Nur, E. (2014). Penerapan e-government publik pada setiap skpd berbasis pelayanan di kota palu. Jurnal Penelitian Komunikasi dan Opini Publik, 18(3), 123749.

Sosiawan, E. A. (2015, June). Tantangan dan Hambatan dalam implementasi EGovernment di Indonesia. In Seminar Nasional Informatika (SEMNASIF) (Vol. 1, No. 5).

Sudarto, Y. (2006). E-government dan reformasi birokrasi menuju pemerintahan yang baik. Bandung: KNTIK. 